\title{
Grandes projetos urbanos em metrópoles amazônicas: modernização e conflito
}

\section{Large urban projects in cities Amazon: modernization and conflict}

Sandra Helena Ribeiro Cruz - Professora do Instituto de Ciências Sociais Aplicadas da Universidade Federal do Pará, doutoranda do Programa de pós-graduação em Desenvolvimento Sustentável do Trópico Úmido, NAEA/UFPA. E-mail: cruz.sandra761@gmail.com

Edna Ramos de Castro - Professora Associada III do Núcleo de Altos Estudos Amazônicos da UFPA, Doutora em Sociologia pela École des Hautes Études en Sciences Sociales (EHESS), Paris, e Pesquisadora do CNPq. E-mail: edna.mrcastro@gmail.com

Maria Elvira Rocba de Sá - Professora Associada III do Instituto de Ciências Sociais Aplicadas da UFPA, Doutora em Serviço Social pela Universidade Federal do Rio de Janeiro (UFRJ), Coordenadora do Programa de Apoio à Reforma Urbana. E-mail: marel.rdsa@gmail.com

\section{Resumo}

Compreender a dinâmica das cidades amazônicas, e da urbanização, pressupõe a análise histórica do processo de crescimento econômico e da relação sociedade x natureza. A densidade urbana esteve na Amazônia diretamente relacionada às políticas de exploração dos recursos naturais como verificado com a intensificação da extração de borracha em fins do século XIX, fator determinante na formação das metrópoles, observando-se na ocasião importantes intervenções urbanísticas. Belém e Manaus tornaram-se expressões urbanas da nova dinâmica econômica, social e política. Nos últimos anos, o poder público, aliado às agências multilaterais de financiamento internacional, procurou responder às demandas da população por moradia e saneamento com expressivas intervenções urbanísticas que demarcam um novo momento de grandes projetos urbanos. Observase, porém, contraditoriamente às demandas por formas sociais de apropriação e de uso do espaço urbano, no âmbito dos conceitos de direito à cidade e reforma urbana, a adoção da mercantilização das cidades como principal estratégia de desenvolvimento, aprofundando conflitos e a segregação social. Neste artigo procuramos mostrar esses processos a partir da análise de dois programas de intervenção urbana: o Portal da Amazônia, em Belém e o Programa Social e Ambiental dos Igarapés, em Manaus.

\section{Palavras-chave}

Grandes projetos urbanos. Metrópoles na Amazônia. Desenvolvimento. Portal da Amazônia. Prosamin.

\begin{abstract}
Understanding the dynamics of Amazonian cities, and urbanization, the analysis assumes the historical process of economic growth and the relationship between society $\mathrm{x}$ nature. Urban density is therefore directly related to the political exploration of natural resources as verified by the intensification of the extraction of latex from rubber trees in the late nineteenth century that was the determining factor for the formation of cities in this region, observing at the time major urban interventions. Belem and Manaus became expressions of the new urban dynamic economic, social and political. In recent years, the government, together with the international multilateral financing agencies, sought to answer the demands of the population for housing and sanitation with significant urban interventions that mark a new era of large urban projects. There is, however, contradictory to the demands for social forms of ownership and use of urban space within the concepts of right to the city and urban reform, the adoption of the commodification of cities as the main development strategy, deepening conflicts and social segregation. In this paper we show these processes from the analysis of two urban intervention programs: the Portal of the Amazon in Belém and the Social and Environmental Program of the streams in Manaus.
\end{abstract}

\section{Keywords}

Large urban projects. Metropole in the Amazon. Development. Amazon Portal. Prosamin. 


\section{INTRODUÇÃO}

As cidades na Amazônia experimentaram um primeiro momento de expressivas intervenções urbanas em consequência do que podemos definir como monopólio econômico, estimulado pela extração da borracha e com objetivo centrado na exportação para países industrializados. Belém e Manaus são expressões desse processo no qual destacamos algumas dimensões: fluxos contínuos de diferentes frações de capital, exploração de recursos naturais crescimento populacional, movimento migratório intenso, esvaziamento de áreas rurais e demandas crescentes por infraestrutura social. Mas as cidades em geral no circuito da borracha tiveram dinamização econômica, investimentos urbanos e crescimento demográfico.

Um segundo momento de intervenção com repercussões nas áreas urbanas, seria configurado a partir dos anos $1970 \mathrm{com}$ as políticas nacionais de desenvolvimento, incluindo a estratégia financeira dos incentivos fiscais e a definição, para efeitos do planejamento do desenvolvimento, de cidades-pólo (Imperatriz, Açailândia, Santarém, Marabá, Altamira, Alta Floresta, Sinop, entre outras). Entre as mudanças que ocorreram na sociedade e na economia regionais, o avanço da fronteira agrícola se faria com diferenciação interna do uso do solo e da estrutura da propriedade. A política de substituição de importações via industrialização nacional, ao qual o processo de conquista de novas terras e recursos naturais para o mercado estava ligado, se prolongaria por toda a segunda metade do século XX.

Assim, a expansão do capital ocorrida a partir da década de 1970 desencadeou novos processos em que o urbano se tornaria a mediação fundamental do movimento de globalização, com sérios impactos na economia e o uso da terra. O Estado teve papel central na gestão e na produção desse movimento. Tais fatores constituíram elementos geradores de conflitos pela disputa na ocupação do território e pela apropriação marcadamente desigual da infraestrutura produzida, pelo Estado, como rodovias, hidrelétricas, portos, equipamentos e serviços coletivos, notadamente os localizados nas áreas urbanas.

Os resultados da pesquisa ora em curso sobre grandes projetos urbanísticos ${ }^{1}$ revelam mudanças por eles provocadas na fisionomia das cidades de Belém e Manaus ao criar condições para atrair investimentos de interesse do mercado, com ênfase no mercado imobiliário, sem levar em consideração que a cidade se constitui um território de heterogeneidades e de diversidades sociais. Entendendo a cidade

\footnotetext{
Pesquisa realizada com apoio do Conselho Nacional de Desenvolvimento Científico e Tecnológico (CNPQ), por meio do Edital MCT/CNPq 02/2009 - Ciências Humanas, Sociais e Sociais Aplicadas.
} 
enquanto lugar de complexidade, o presente estudo pergunta: de que forma o modelo adotado nas intervenções urbanisticas recentes tem incorporado avanços conceituais e processuais quanto ao direito à cidade, à função social da terra e do espaço urbano? E que estratégias estão em jogo - do Estado, de empresas e de moradores dos lugares de intervenção - para viabilizar de um lado a implantação dos projetos, e de outro, por parte da população, para garantir direitos que consideram conquistados pelo tempo de ocupação nessas áreas que são espaços centrais da cidade, com serviços urbanos e mais facilidades de acesso ao trabalho.

Interessa portanto analisar as relações que se estabelecem diante da execução de políticas de renovação urbana nas metrópoles de Belém e Manaus, a partir da análise de dois grandes programas de intervenção urbanística: Portal da Amazônia, em Belém, e o Programa Social e Ambiental dos Igarapés de Manaus (PROSAMIM) cuja origem se dá com base na estratégia de internacionalização da política urbana, com vistas a vender certa imagem da Amazônia como região desenvolvida e com fortes atrativos para investimentos pelas grandes empresas, corporações e potências nacionais.

\section{PADRÕES DE URBANIZAÇÃO, CRESCIMENTO ECONÔMICO E DEMOGRÁFICO}

A produção das cidades na Amazônia resulta das relações produzidas pela dinâmica de atores sociais com origens diversas, em períodos diferentes de sua constituição histórica, mas sobretudo, pelas relações econômicas relacionados à produção de territórios, entendendo este como espaço de ação coletiva e de relações sociais A partir dessa perspectiva, é possível apontar elementos para explicar os processos que determinam singularidades das metrópoles amazônicas, enriquecendo abordagens mais centradas na explicação econômica da vida urbana. E por isso, entende-se necessário decifrar os parâmetros e particularidades da urbanização na Amazônia como resultantes de diferentes dinâmicas nas relações econômicas, sociais, políticas e culturais nestas cidades, ou seja, [...] incorporando à análise os sujeitos sociais que fazem a cidade, que lutam em posições de classe diferentes e que são os artífices da produção do espaço, da construção de direitos à cidade e da possibilidade de construir a cidade segundo os valores e as singularidades dos individuos e grupos sociais que a compõem (CASTRO, 2008, p. 14)

Para Nunes a atração que a cidade exerce sobre os individuos e as empresas (de portes diversos) explica-se, sobretudo, pela chamada "economia de urbanização", que seriam justamente as vantagens que o sitio urbano oferece na escolha de um sitio locacional, ou para as atividades produtivas, ou até mesmo para migrantes potenciais. (2008; p. 48) 
O crescimento das metrópoles na Amazônia data do final do século XIX e início do século XX, quando a região experimentou maior inserção nas formas de desenvolvimento capitalista, mesmo sob bases agroexportadoras, em decorrência da exploração dos recursos naturais para fins de exportação. Esse tipo de economia possibilitou o desenvolvimento de uma base produtiva exclusivamente agroexportadora, sem estímulos para a prática do beneficiamento e a transformação de produtos primários em secundários. Paralelamente, desencadeou um movimento migratório intenso para a região, sobretudo de nordestinos, que se constituíram força de trabalho fundamental à produtividade da extração e comercialização do látex.

Nunes e Hatoun (2005) comparam a influência econômica sobre a cultura amazônica nas cidades de Belém e Manaus, expressando que as mudanças ocorridas no período da exploração da borracha determinaram a complexidade das questões sociais na contemporaneidade amazônica. Nunes (2005) constata que:

[...] mudou a classe dominante, sustentada hoje nas especulações do capital que a desligam do solo urbano, sem nenhum outro discurso ideológico senão o do lucro imediato, e mudaram as dominadas, massa anônima incrustada numa população de mais de 1.300.000 habitantes. A população se massificou e o traçado urbano da cidade cêntrica está sendo descentrado da sua história (NUNES, 2005, p. 41).

Enquanto Hatoun (2005) refere-se à política excludente:

[...] quando hoje presenciamos as deploráveis condições de habitação nas dezenas de bairros da periferia de Manaus, esquecemos que essa miséria urbana tem fundas raízes no vazio econômico do interior do Amazonas, mas faz parte também do processo histórico da cidade e de sua política excludente (HATOUN, 2005, p. 55).

Nessa região, os índices de urbanização tiveram crescimento lento até os anos 1960, quando a situação se altera em função do desenvolvimento das telecomunicações, da infraestrutura rodoviária, do consumo e da maior amplitude no intercâmbio com as demais regiões do país, estimulado pela industrialização e pela modernização da economia e do Estado brasileiro. Momento em que se presencia uma expansão da ocupação urbana implementada pelos programas governamentais de ocupação e colonização dirigida, atendendo estratégias institucionais dos governos militares, associado aos interesses do mercado, para ocupação de terras na Amazônia o que contribuiu sobremaneira para mudar a fisionomia das cidades nessa região, conforme síntese apresentada no Quadro 1. 


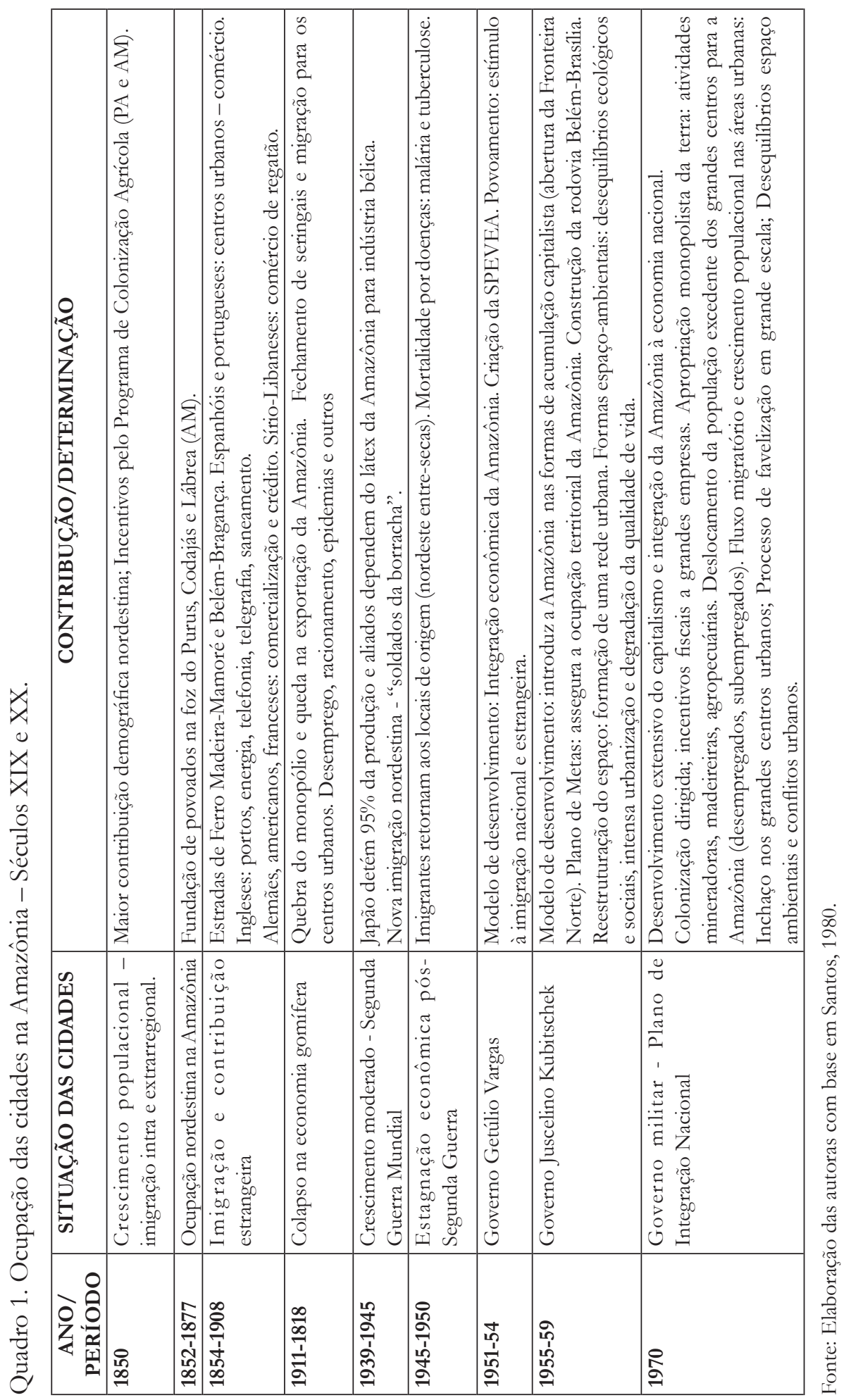


Os acontecimentos relativos à economia regional provocaram o surgimento de diversas cidades e o explosivo adensamento populacional das já existentes. Assim, foi se consolidando a estrutura de uma Rede Urbana sob a forma dendrítica, que, no entanto, sofre mutações, e hoje é formada a partir de múltiplos circuitos, como mostra Trindade (1998). Santos (2008) refere-se que no século XIX, havia em Belém 50.064 habitantes; e em 1900 esta encontrava-se entre as cinco capitais mais populosas do Brasil, com 96.560 habitantes, enquanto Manaus, nesse primeiro ano do século XX, contava com 50.300 habitantes.

Para Santos a urbanização brasileira seguiu uma lógica em que os nexos econômicos necessários se deram sob uma articulação entre a economia agrícola e a industrialização, e consistiu numa ferramenta tecnológica e política determinante para a acumulação capitalista, por meio do movimento industrial nacional ${ }^{2}$. A economia brasileira, até a Segunda Grande Guerra cresceu com base nas atividades extrativa. Mas após "os anos 1930, novas condições políticas e organizacionais permitem que a industrialização conheça, de um lado, uma nova impulsão, vinda do poder público e, de outro, comece a permitir que o mercado interno ganhe um papel, que se mostrará crescente, na elaboração, para o país, de uma nova lógica econômica e territorial, materializada pela industrialização (SANTOS...).

O crescimento da industrialização nacional exerceu forte influência sobre as cidades amazônicas, principalmente a partir dos anos 1970, com a abertura da rodovia Belém-Brasília, que tinha em sua centralidade a ligação das regiões industrializadas à região amazônica como fonte de matérias-primas e um potencial mercado consumidor. As rodovias viabilizaram fluxos migratórios intensos, estimulados pelas promessas governamentais de acesso a terras abundantes e de fácil aquisição, cujos efeitos sobre as cidades vão ser catastróficos, dada à falta de infraestrutura e serviços coletivos para atender uma demanda crescente, o que agravou mais o quadro já deficiente desses serviços.

Por isso é impossível não associar o crescimento das cidades amazônicas ao movimento de industrialização nacional, sobretudo no que tange ao fenômeno da urbanização. Segundo Santos, nos anos entre 1940-1980 o Brasil vive uma "verdadeira inversão quanto ao lugar de residência da população brasileira", com um aumento da taxa de urbanização que passa de 26,35\% em 1940 para 68,86\%

2 Ao refletir sobre a industrialização durante a República Velha Warren Dean (1977) demonstra claramente que nesse período a transição para industrialização da economia exigiu uma aliança entre os representantes da economia agrária e a nova classe industrial. Para esse autor, "a elite agrária frequentemente condescendia em estabelecer alianças com a nova classe industrial, e os industriais frequentemente adquiriam terras, não só para rematar a sua busca de integração vertical, mas também para tentar atingir o nível máximo de status cujo sentido já traziam de sua terra natal e tornavam a encontrar no Brasil" (DEAN, 1977, p. 275). 
em 1980 (2008, p. 31). Entre 1950 e 1991, a população urbana brasileira atinge uma taxa de $77 \%$ da população total.

No século XX, a lógica da industrialização, vista como processo social complexo, possibilitou a formação de um mercado nacional. Os esforços para equipar o território e integrá-lo expandiram o consumo sob formas diversas e estimularam a vida social, ativando o próprio processo de urbanização como condição de modernidade. Essa fase mais intensiva da urbanização no Brasil impulsionou as cidades a buscarem investimentos políticos e tecnológicos, o que as tornou, contraditoriamente, espaços de disputas e fortes tensionamentos sociais.

A Amazônia, seguindo o processo de industrialização e urbanização no Brasil, passa a ser integrada mais intensivamente às demais regiões, através de programas, projetos e políticas do Estado brasileiro. Listam-se aqui as políticas de colonização dirigida, os incentivos à ocupação espontânea, a criação de órgãos de planejamento do desenvolvimento que tiveram importante função de mediadores entre as estratégias do Estado e os interesses do mercado, como a Superintendência da Amazônia (SUDAM), o Banco da Amazônia (BASA) e a Zona Franca de Manaus (ZFM), os incentivos fiscais, a redefinição das formas de ocupação de terras, entre outras. Tais medidas tiveram um caráter territorial, desde a abertura de novas fronteiras ao ordenamento de territórios segundo critérios de mercado, e com significativa repercussão na reorganização espacial das cidades.

Já nos anos 1980, foi dada continuidade ao planejamento do desenvolvimento regional, com a implantação de grandes projetos promovidos pelo Programa Grande Carajás (PGC), fundamentado em um modelo exógeno, no entanto com desenvolvimento de base extrativo-mineral. Nesse sentido não é diferente, quanto à agregação de valor, aos sistemas acumulados, social e economicamente na região, como o extrativismo da castanha, da seringa, da madeira, da agricultura familiar, de frutas tropicais e de grãos - ou mesmo da pecuária. Mas é de grande diferença pelo porte (capital, trabalho, tecnologia), inserção em mercados globalizados, formas de gestão e capacidade de mobilização recursos financeiros do Estado e o setor privado. Este modelo fomentou novas territorialidades, sob o controle de empresas públicas e privadas comprometidas em atender agendas controladas pelos interesses do mercado nacional e internacional.

\section{BELÉM E MANAUS: HISTORICAMENTE SEMELHANTES E DIFERENTES}

Considerando o espaço como base e instrumento para o desenvolvimento regional, o Estado brasileiro passa a garantir os meios necessários tanto para a 
reprodução do capital, quanto para a força de trabalho assalariada que se gerou em função dos projetos implantados. Novos territórios e territorialidades estão em jogo. Os espaços urbanos tradicionais se adensam, adquirindo inusitado crescimento. Essa é a tendência observada em praticamente todas as cidades nos estados do Para, Maranhão, Mato Grosso e Rondônia, sobretudo, tiveram crescimento demográfico expressivo. Exceção do estado do Amazonas, com a forte atração de Manaus devido inúmeros fatores, entre eles a possibilidade de trabalho assalariado concentrado no seu espaço urbano.

O crescimento demográfico de Manaus foi surpreendente. A cidade abrigava em 1970 o equivalente a metade da população de Belém que era à época a maior cidade da Amazônia. Dez anos depois, já estava com quase 70\%, e em 1990 atingiu mais de $80 \%$, chegando aos dias atuais com um crescimento populacional de 478,03\% entre os anos de 1970-2010, enquanto que Belém cresceu 120\% em relação ao mesmo período, como se pode observar nos dados da Tabela 1.

Tabela 1. Evolução da População da cidade de Belém entre 1960 e 2010

\begin{tabular}{l|c|c|c|c|c}
\hline \multicolumn{1}{c|}{ Anos } & $\mathbf{1 9 7 0}$ & $\mathbf{1 9 8 0}$ & $\mathbf{1 9 9 1}$ & $\mathbf{2 0 0 0}$ & $\mathbf{2 0 1 0}$ \\
\hline População Belém & 633.374 & 933.322 & 1.244 .689 & 1.280 .614 & 1.393 .399 \\
\hline População Manaus & 311.622 & 633.392 & 1.011 .501 & 1.405 .835 & 1.802 .014 \\
\hline $\begin{array}{l}\text { Variação Percentual de } \\
\text { Belém/Manaus }\end{array}$ & $103,00 \%$ & $47,00 \%$ & $23,00 \%$ & $-9,00 \%$ & $-23,00 \%$ \\
\hline
\end{tabular}

Fonte: IBGE/Censos 1970, 1980, 1991, 2000, 2010

Assim, as duas cidades chegam ao ano de 2010 com uma diferença no crescimento populacional mais acentuada entre elas. Em termos absolutos Manaus tem 410.494 habitantes a mais do que Belém, pois Manaus possui 1.802.014 habitantes e Belém 1.393.399 habitantes. Em termos percentuais, a população de Belém representa aproximadamente $25 \%$ da população do estado do Pará e Manaus tem uma população que representa 75\% dos habitantes do Amazonas, o que significa uma diferença quantitativa do crescimento demográfico de Manaus em relação a Belém, em decorrência do baixo investimento que viabilizasse a inserção de Belém na dinâmica do capital internacional instalado na região, como ocorrera em Manaus, com a instalação da ZFM.

Belém e Manaus enquanto duas metrópoles que se encontram em pleno processo de crescimento demográfico, vivem os impactos do capitalismo em sua face globalizada, onde a cidade vive a realidade de um mundo segregado social e territorialmente, materializando as diferentes maneiras de apropriação e disputa pela ocupação da terra e pelo acesso à moradia enquanto uma das condições básicas à reprodução da vida. Essa tendência demográfica gerou inúmeras demandas para as duas cidades em termos de infraestrutura urbana, de trabalho e serviços. 
O comportamento demográfico das duas cidades deve ser associado às relações econômicas que se estabeleceram em ambas. A criação da Zona Franca de Manaus (ZFM), em 1967, significou fator atrativo tanto para empresas como para trabalhadores do Amazonas e de outras cidades do país, exercendo sobre a região a imagem de fator positivo para o desenvolvimento regional e nacional, e que, mais do que referência para o mercado nacional e internacional, constituise em elemento de representação social e simbólica para a população habitante daquela cidade, que se orgulha em ter um parque tecnológico avançado, embora, contraditoriamente, não consiga superar os índices de pobreza na cidade, inclusive o avanço acelerado de um mercado informal que concorre desigualmente com o mercado formal.

[...] os números gerados pelo Polo Industrial de Manaus mostram um lado econômico importante, que muitas vezes esconde a dura realidade de uma cidade que atinge 1,7 milhões de habitantes em 2006 e que tem ampliado seus domínios espaciais, com a interiorização pelas 'terras firmes', em um modelo de ocupação mista, com intervenções planejadas pelo Estado (conjuntos habitacionais) e ocupações espontâneas (invasões) (OLIVEIRA; SCHOR, 2008, p. 83).

Desse modo, a periferia recente de Manaus, com sua expansão em direção ao Norte e ao Leste da cidade, foi criada a partir de invasões, de migração das cidades do interior do estado do Amazonas, do Pará e do Maranhão. Contingentes sem emprego e sem renda, muitas vezes com trajetória em garimpos, canteiros de obras de grandes projetos, de estradas ou mesmo vindos das áreas ribeirinhas, da agricultura familiar, de comunidades pesqueiras, ou da pecuária ou expulsos de áreas com agricultura mecanizada, como a soja. Já a cidade de Belém apresenta certa estagnação demográfica em decorrência principalmente da instalação de projetos econômicos em cidades médias, constituindo fator de desconcentração econômica e urbana no Pará. Contudo, essa cidade continua sendo a mais adensada do Estado tanto porque oferece uma rede de serviços mais consolidada, principalmente em relação aos aspectos de educação e saúde, tornando fator atrativo para segmentos populacionais e empresariais, como pelo fato de que Belém apresenta uma extensão territorial bastante estreita, originando bairros e áreas superadensadas como veremos à seguir:

Tabela 2. População das cidades de Belém e Manaus - 2010

\begin{tabular}{l|c|c|c|c|c}
\hline Cidades & Urbana & $\mathbf{\%}$ & Rural & $\mathbf{\%}$ & Total \\
\hline Belém & 1.380 .836 & 99,2 & 11.195 & 0,8 & 1.392 .031 \\
\hline Manaus & 1.793 .416 & 99,5 & 9.109 & 0,5 & 1802525 \\
\hline
\end{tabular}

Fonte: IBGE, 2010 
Ao analisar as relações campo e cidade na Amazônia, Nunes (2008; P. 42) considera que,

[...] A transferência dos indivíduos do campo para a cidade (é esse o sentido histórico da migração nos últimos séculos) deve ser sempre tida como o resultado de fenômenos que vão pouco a pouco se complexificando, ou porque se desestruturam sem oferecer alternativas (como a crise do feudalismo na Europa medieval), ou porque as cidades se apresentam como espaços de liberdade e de autonomia, em relação a um mundo rural restritivo. Entre os fatores de expulsão de um lado e os de atração de outro, é todo o capitalismo que se vai consolidando na sua base territorial: a cidade.

$\mathrm{Na}$ região amazônica esse processo de consolidação do capitalismo foi bastante diversificado, como efeito das dinâmicas impulsionadas pelas políticas de desenvolvimento do governo federal sobre a expansão do mercado nos estados do Pará e Amazonas, nos últimos 40 anos. No primeiro caso, como expõe Castro (2007) possibilitou o avanço da fronteira agrícola, da pecuária, da exploração madeireira e mineral extensiva, com incidência de recursos e de terras para a pecuária e colonização, originando o crescimento demográfico de pequenas cidades e o aparecimento de muitas outras no correr desses projetos, e de abertura de novas fronteiras urbanas. Tal dinâmica se reflete, mas recentemente, na dinâmica das cidades de fronteiras políticas entre o Brasil e países Pan-Amazônica CASTRO, 2007, 2009, 2011).

No que se refere ao Produto Interno Bruto (PIB), o de Manaus é duas vezes e meia maior que o de Belém. Segundo dados do IBGE (2009), Belém apresenta um PIB em torno de $\mathrm{R} \$ 10.754,77$, enquanto que o PIB de Manaus se encontra em torno de R\$22.303,26. Entretanto, chama atenção o fato de que em Manaus o índice de GINI revela uma maior concentração de renda do que na cidade de Belém, ou seja, a partir de dados do IBGE (2003), Manaus apresenta um índice de Gini de 0,49 e Belém, de 0,43.

Outro elemento importante que demonstra as diferenças entre as duas cidades está na composição socioeconômica, proveniente do rendimento salarial da população, conforme a Tabela 3 .

Constata-se na tabela 3, que mais de $82 \%$ das populações destas capitais recebem como renda até três salários mínimos $(82,2 \%$ da população de Belém e em Manaus este número atinge 82,4\%). Tanto Belém quanto Manaus são cidades com contingente populacional disposto em sua maioria na área urbana, enfrentando um nível de pobreza profundo, com grande parte percebendo salários que não ultrapassam os três salários mínimos, dificultando de forma contínua o acesso aos meios de consumo coletivo, indispensáveis ao bem-estar social da população. 
Os níveis de concentração de renda vistos nas metrópoles amazônicas estão associados ao padrão estabelecido historicamente pela dinâmica da economia capitalista mundial e que na contemporaneidade resulta das alterações que ocorreram no âmbito da produção, alterando as relações de trabalho inauguradas pela industrialização e pelo modelo fordista.

Tabela 3. População das cidades de Belém e Manaus, segundo renda média individual mensal.

\begin{tabular}{l|r|r|r|r}
\hline \multicolumn{1}{c|}{ Classes de renda } & \multicolumn{1}{c|}{ Belém } & \multicolumn{1}{c|}{$\boldsymbol{\%}$} & \multicolumn{1}{c|}{ Manaus } & \multicolumn{1}{c}{$\%$} \\
\hline Sem rendimento & 467.163 & 44,9 & 523.724 & 48,4 \\
\hline Até 1/2 de salário mínimo & 24.868 & 2,4 & 16.931 & 1,6 \\
\hline Mais de 1/2 a 1 salário mínimo & 143.902 & 13,8 & 115.241 & 10,6 \\
\hline Mais de 1 a 2 salários mínimos & 151.744 & 14,6 & 158.416 & 14,6 \\
\hline Mais de 2 a 3 salários mínimos & 67.085 & 6,5 & 77.822 & 7,2 \\
\hline Mais de 3 a 5 salários mínimos & 67.312 & 6,5 & 79.352 & 7,3 \\
\hline Mais de 5 a 10 salários mínimos & 65.903 & 6,3 & 66.853 & 6,2 \\
\hline Mais de 10 salários mínimos & 51.918 & 5,0 & 44.562 & 4,1 \\
\hline Total & $\mathbf{1 . 0 3 9 . 8 9 5}$ & $\mathbf{1 0 0 , 0}$ & $\mathbf{1 . 0 8 2 . 9 0 1}$ & $\mathbf{1 0 0 , 0}$ \\
\hline
\end{tabular}

Fonte: IBGE, 2010

O estado do Amazonas o modelo governamental observado nos planos de desenvolvimento, nos programas e nos investimentos priorizou o adensamento de capital industrial pela instalação da Zona Franca de Manaus e depois pelos desdobramentos na verticalização via produção de componentes e periféricos para o parque industrial, exemplo observado hoje no Polo Industrial de Manaus. Assim, o adensamento populacional de Manaus corresponde também a uma redução relativa, e mesmo absoluta, de pequenas cidades e povoados do entorno e ao longo das grandes vias de navegação fluvial.

As consequências sobre o espaço urbano na Amazônia e sua urbanização recente, e em especial às metrópoles em análise, exigem uma reflexão, portanto, sobre as dinâmicas regionais, em círculos e escalas mais ampliadas, e sua correlação com os novos projetos desenvolvimentistas propostos no âmbito dos atuais programas do governo federal para a Amazônia. Nesses, são assinalados para o estado do Amazonas investimentos voltados para abrir as fronteiras de mercado para espaços mais amplos, com diversificação de investimentos, o que certamente provocará uma redefinição do modelo urbano dominante até então na perspectiva das políticas governamentais, ressaltando que, na atualidade, também se observa investimentos em políticas direcionadas para abertura de novas fronteiras do 
capital, por parte de governos estaduais dos dois estados. O crescimento de cidades amazônicas nas áreas de fronteiras no Brasil com os demais países que conformam a Pan-Amazônia tem seguido também a lógica da intervenção promovida por políticas direcionadas, com certas diferenciações de estratégias locacionais (CASTRO, 2008, 2011).

Esse padrão de ocupação das cidades amazônicas contribuiu para alterar a configuração das redes urbanas estabelecidas pelo primeiro padrão de ocupação regional. Surgiram alguns elementos que podem ser considerados como determinantes nesse processo, cita-se: o fortalecimento de centros urbanos mais antigos, o surgimento e crescimento de cidades em função dos projetos de colonização, a implantação de novos núcleos urbanos equipados de acordo com as necessidades de empresas instaladas nas cidades da região mais recentemente, a retração econômica de cidades voltadas para a circulação fluvial e a concentração populacional nas capitais estaduais. O crescimento urbano vivenciado em nível regional provocou o aumento por novas demandas sociais, dentre elas o aumento da demanda por moradia. A questão da moradia é um dos principais problemas urbanos enfrentados por toda grande cidade, principalmente por aquelas que tiveram crescimento acelerado no último século. Crescimento que se fez de maneira 'selvagem' e desordenada do ponto de vista do planejamento urbano, o que tornou a urbanização espoliativa, violenta e segregadora, pois a materialidade das relações sociais inscritas pelo capitalismo em meio urbano-metropolitano, é que imprime as desigualdades sócio-territoriais em todo o país (RIBEIRO, 2005)

\section{PORTAL DA AMAZÔNIA E PROSAMIM: GRANDES PROJETOS DE INTERVENÇÃO URBANÍSTICA EM BELÉM E MANAUS}

A intervenção urbanística deve ser entendida conceitualmente como processo de investimento econômico e social realizado pelo poder público nas cidades, com o intuito de garantir melhores condições de habitabilidade em suas áreas urbanas. Tal definição está referida à perspectiva analítica que tem nas condições gerais da produção capitalista ${ }^{3}$ o elemento explicativo das relações sociais na cidade capitalista.

\footnotetext{
Para Lojkine, o conceito "condições gerais de produção" corresponde ao que Marx definiu como produção e reprodução do capital, a partir da relação entre o consumo produtivo e o consumo individual da classe trabalhadora, onde o primeiro opera como "força motriz do capital e pertence ao capitalista; no segundo, pertence a si mesmo e realiza funções vitais fora do processo de produção. O resultado de um é a vida do capitalista e o do outro é a vida do próprio trabalhador" (MARX, 1985, p. 665). Ainda para o autor, a socialização das forças produtivas proposta por Marx abrange simultaneamente a divisão técnica do trabalho na oficina e a divisão do trabalho no conjunto de uma sociedade. Assim, Marx foi levado a desenvolver um novo conceito para definir a relação entre o processo imediato de produção, a unidade de produção por um lado, e, por outro, o processo global de produção e de circulação do capital: é o que ele chama as condições gerais da produção (LOJKINE, 1981, p. 123).
} 
Essa análise encontra nos equipamentos e serviços coletivos a chave teórica para explicar como se dá o atendimento das reivindicações da classe trabalhadora, que ao funcionarem cumprem, contraditoriamente, uma função estratégica no aumento da rentabilidade do capital. Estas novas condições vão se tornar cada vez mais significativas no processo de produção capitalista, e pouco a pouco responsáveis pela criação de um novo modo de vida (urbano) e de novas necessidades sociais ${ }^{4}$.

Portanto é fundamental pensar os processos de intervenção urbanística com vistas às melhorias de habitabilidade, enquanto um dos elementos que determina o processo de acumulação capitalista na cidade, dado que tais processos, ao se realizarem, tornam a cidade mais competitiva e mais segregadora. Nesse sentido, à luz da perspectiva analítica de Jean Lojkine, considera-se que a intervenção urbanística nas cidades de Belém e Manaus tem contribuído para determinar as condições gerais da produção capitalista nessas cidades.

Buscando ampliar a perspectiva analítica de Marx, esse autor assinala que no contexto da urbanização, enquanto elemento-chave das relações de produção deu-se o aparecimento de fatores também importantes, que são outras tantas condições necessárias à reprodução global das formações capitalistas desenvolvidas. Trata-se, de um lado, dos meios de consumo coletivos que vêm se juntar aos meios de circulação material; de outro, da concentração espacial dos meios de produção e de reprodução das formações sociais capitalistas.

Desse modo, o que vai caracterizar duplamente a cidade capitalista é,

[...] de um lado, a crescente concentração dos 'meios de consumo coletivos' que vão criar pouco a pouco um modo de vida, novas necessidades sociais - chegou-se a falar de uma 'civilização urbana' -; de outro, o modo de aglomeração específica do conjunto dos meios de reprodução (do capital e da força de trabalho) que se vai tornar, por si mesmo, condição sempre mais determinante do desenvolvimento econômico" (LOJKINE, 1981, p. 124).

Essa caracterização possibilita o entendimento do papel desenvolvido pelos meios de consumo coletivos no processo de acumulação do capital, como é o caso dos serviços de educação, saúde, transporte etc. Para o autor,

[...] à primeira vista, por conseguinte, não há nenhum motivo para colocar os meios de consumo coletivos em outra esfera que não seja a do consumo final e improdutivo, assim como os meios de consumo individuais. Em que seu modo social de consumo pode mudar-lhes a função? Quer se trate de despesas de ensino ou de saúde, não participam elas da reprodução da força de trabalho e, por isso, dos gastos com renda? (, Op. cit.).

Id. ibidem. 
A tentativa do autor é de deixar clara a importância que os serviços de educação e saúde desempenham no processo de produção das relações capitalistas, pois, segundo ele, o nível atingido pela socialização interna da produção industrial no século XX fez da formação profissional, por exemplo, um fatorchave para aumentar a produtividade do trabalho. Isso pressupõe que o capital para se reproduzir admite a importância dos equipamentos coletivos, enquanto retaguarda que contribui para o processo de reprodução da classe trabalhadora e, consequentemente, das condições gerais de produção, tornando-se elemento essencial no desenvolvimento das cidades capitalistas.

Assim,

[...] a aglomeração da população, dos instrumentos de produção, do capital, dos prazeres e das necessidades - em outras palavras a cidade - não é de modo algum um fenômeno autônomo sujeito a leis de desenvolvimento totalmente distintas das leis de acumulação capitalista, onde a esfera da produção, a da troca e a do consumo estão em constante interação (Id ibidem; p. 139, grifo do autor).

Como consequência desse processo de acumulação capitalista, as cidades passaram a conviver com dinâmicas econômicas e sociais que alteraram o modo de vida e organização do território, gerando novas disputas pelo lugar de morar, de trabalhar e de viver, caracterizando-a como uma cidade segregadora.

No cerne desse debate localizamos os processos de intervenção urbanística enquanto condição para o avanço da acumulação capitalista na Amazônia, a partir dos investimentos realizados pela política urbana na infraestrutura urbana de suas metrópoles, que ao receber investimentos, agrega maior valor econômico ao território. Pois, ao receber infraestrutura urbana, o território sofre modificações, tornando a fisionomia das cidades atrativa para novos investimentos e novas relações socioeconômicas e culturais.

\subsection{O Portal da Amazônia}

A Prefeitura Municipal de Belém (PMB) deu início no ano de 2006 ao projeto de intervenção urbanística localizado na Bacia Hidrográfica da Estrada Nova. Essa Bacia Hidrográfica compreende uma extensão territorial de $9,54 \mathrm{~km}^{2}$, dos quais $72,70 \%$ do solo são constituídos de áreas alagáveis devido aos efeitos das marés e das constantes chuvas, em cujos limites residem aproximadamente $250.000 \mathrm{mil}$ pessoas, o que corresponde a 15,60\% da população total de Belém (BELÉM, 2003). "Portal da Amazônia". Este se constitui em projeto municipal de urbanização da orla do rio Guamá e está composto de duas grandes intervenções urbanísticas: o projeto Orla e o PROMABEN, conforme mostra Figura 1, abaixo, sinalizando na 
parte sombreada a grande área de intervenção do projeto urbanístico. O projeto de intervenção urbanística PROMABEN está sendo realizado desde 2009 a partir de convênio firmado com o Banco Interamericano de Desenvolvimento (BID), no valor de $\mathrm{U} \$ 137.500$, com contrapartida da Prefeitura na ordem de 50\% do valor total do programa e que tem como ação Guajará e dos igarapés que estão localizados na porção Sul de Belém.

Bacia Hidrográfica da Estrada Nova

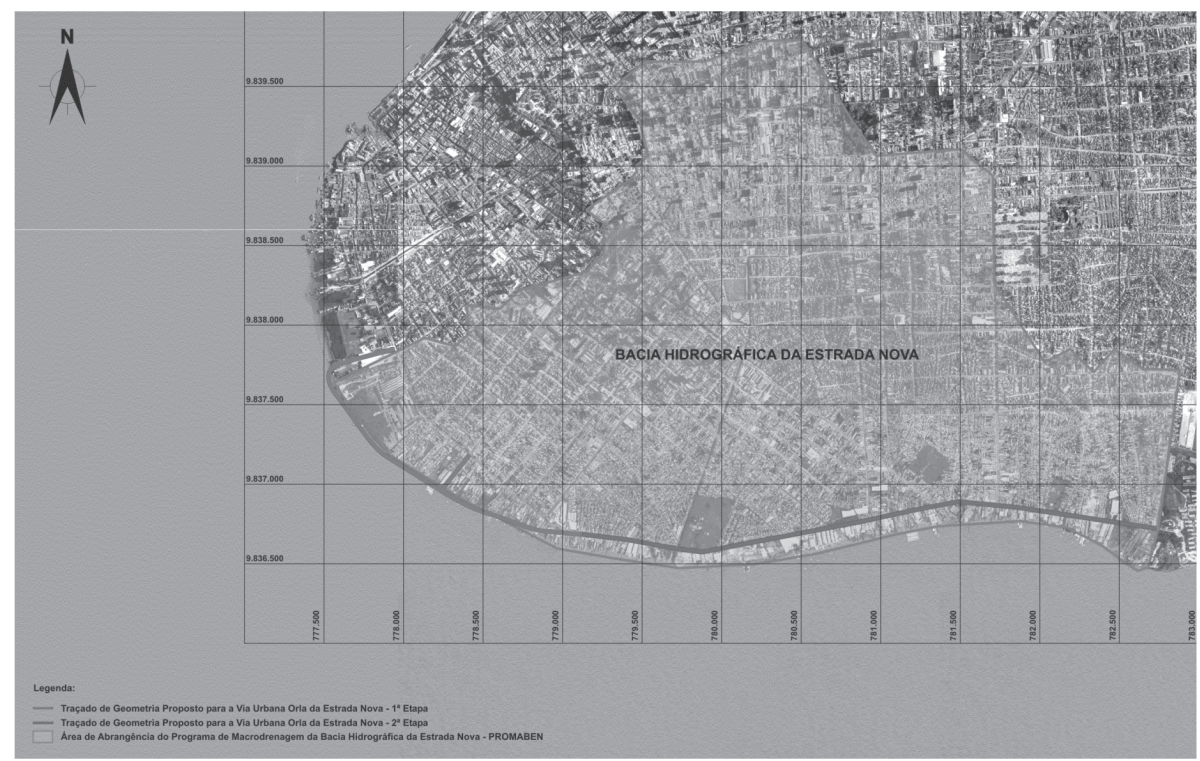

Fonte: PMB, 2003

De acordo com o estudo de impacto ambiental realizado pela empresa terceirizada ENGESOLO (2007), o PROMABEN obedecerá estrategicamente quatro pilares básicos de obras estruturantes: 1) Drenagem da bacia, com adequação do sistema de macro e microdrenagens; 2) Saneamento básico, com melhoria nos serviços de abastecimento de água e esgotamento sanitário; 3) Urbanismo e habitação, com implantação de novas vias urbanas e equipamentos urbanísticos, melhoria na habitação e o reassentamento e relocação da população das áreas de risco; 4) Revitalização urbano-ambiental, com a implantação de infra-estrutura urbana que proporcionará a implantação e desenvolvimento de atividades e a integração sócio-econômica da população residente na bacia.

Há a prevalência, nas áreas que margeiam os diversos cursos d'água que compõem esta bacia hidrográfica, a semelhança do que ocorre com as outras existentes na extensão territorial do município de Belém, da ocupação humana 
em casas do tipo palafitas (vide Figura 2 e 3), impactadas pelo fluxo das marés e das chuvas constantes na região, características propícias à propagação de doenças veiculadas por meio hídrico, tornando-as inadequadas para este tipo de ocupação pelo alto índice de insalubridade.

Figuras 2 e 3. Habitação do tipo palafita na área do Projeto "Portal da Amazônia" e Aspectos das Moradias na Bacia da Estrada Nova.
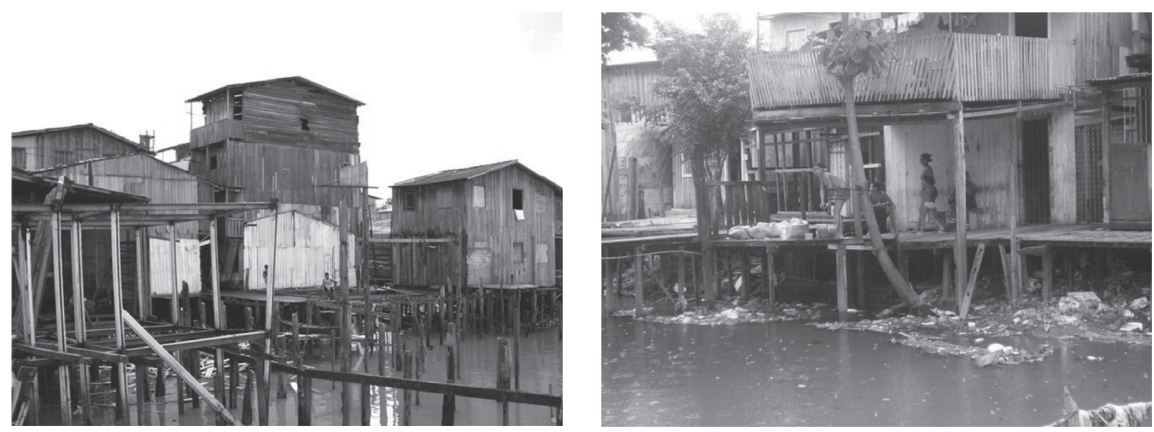

Fonte: Prefeitura Municipal de Belém (2003).

Ao longo de sua extensão na orla fluvial sul da cidade de Belém, a BHEN é também ocupada por portos, trapiches e feiras, que fazem parte da logística necessária às atividades econômicas e sociais desenvolvidas em seus territórios, ao mesmo tempo em que expressam a materialidade da identidade ribeirinha que esta cidade apresenta. Segundo pesquisa realizada, em 2009, pelo Projeto Nova Cartografia Social da Amazônia, foram identificados quatro portos públicos e 28 portos privados onde os trabalhadores comercializam e movimentam não só os produtos provenientes das ilhas e municípios circunvizinhos, principalmente o açaí, produto bastante consumido em Belém, como circulam as mercadorias demandadas pelos moradores destas ilhas e cidades próximas ${ }^{5}$.

5 Os portos existentes na orla da Estrada Nova servem para atracação de barcos que atendem produtores ribeirinhos, estudantes, deficientes físicos e a comunidade em geral que os utilizam como transporte entre as ilhas e Belém e dependem do trapiche, como o Porto do Açaí para desembarcar. Esse porto é o único Porto 24 horas e um dos portos públicos de maior movimento de Belém, onde atracam barcos que trazem a produção dos ribeirinhos que moram nas ilhas de Barcarena, Acará e Marajó entre outras. Os produtos mais comercializados são o açaí, farinha, sementes de cacau e frutas regionais. "O grosso da comercialização destes produtores ribeirinhos se dá exatamente no centro do trapiche, como é que vamos ficar aqui sem ele? Como os barcos que chegam do outro lado da orla vão atracar e descarregar seus produtos? Isso é a mesma coisa que fechar o porto. Como é que dizem que não vão acabar com o Porto se querem retirar o nosso trapiche, que é fundamental para o trabalho que desenvolvemos aqui?” (PORTAL CULTURA, 2010). 
O PROMABEN prevê a macro e microdrenagem de quatro sub-bacias da BHEN, das quais a Sub-bacia 1 estende-se da travessa Veiga Cabral à Rua Fernando Guilhon; a Sub-bacia 2 entre a rua Fernando Guilhon até o canal da travessa Quintino Bocaiúva; a Sub-bacia 3, do canal da Quintino Bocaiúva ao canal da travessa 3 de Maio; e a Sub-bacia 4, do canal da 3 de Maio à Universidade Federal do Pará (UFPA) (BELÉM, 2010b).

O Projeto Orla compreende os investimentos em uma linha viária numa extensão de seis quilômetros, entre o Mangal das Garças ${ }^{6}$ e a Universidade Federal do Pará. Uma vez que esse projeto contará com recursos próprios, foi apresentado como contrapartida ao financiamento obtido junto ao BID e está sendo desenvolvido em uma primeira etapa denominada insular (correspondendo ao aterramento de uma área litorânea), em fase de execução, que será seguida da etapa continental, prevendo-se na primeira, a construção de

[...] seis pistas, com largura de 70 metros, com área de passeio, estacionamento e ciclovia. Parte do espaço deverá ser reservado para área de lazer, incluindo quadras de esporte, áreas com equipamentos de ginástica, restaurantes e quiosques, nos moldes das orlas construídas nos grandes centros, como Recife e Rio de Janeiro. Com o projeto, a prefeitura pretende fazer com que Belém desponte definitivamente para o turismo com objetivo de gerar emprego e renda, aliado às outras obras que abriram algumas janelas para o rio, como a Estação das Docas, as Onze Janelas e o Mangal das Garças (BELÉM, 2010a).

A intervenção realizada pelo projeto Portal da Amazônia tanto pelo projeto Orla quanto pelo PROMABEN prevê o deslocamento compulsório das famílias moradoras dos bairros que compõem a BHEN, bem como de unidades comerciais. Segundo "Relatório do Levantamento Socioeconômico da Área da Orla" na Sub-bacia 1, pela Secretaria Municipal de Habitação (SEHAB), no período de fevereiro a março de 2008 foram cadastrados 388 imóveis nas nove vilas existentes nas áreas objeto do projeto orla, com a identificação das benfeitorias fechadas, imóveis estes que serão diretamente atingidos pela execução das obras na orla fluvial (MALHEIRO, 2009, p. 122). O número de famílias cadastradas pela PMB, que serão atingidas por essa intervenção, por remoção ou por reassentamento nas quatro sub-baciais mencionadas, totaliza 2.129 famílias. A distribuição dessas famílias, percentualmente, pelas quatro (4) Sub-baciais é a seguinte: Sub-bacia 1 - 16,16\%; Sub-bacia 2 - 44,2\%; Sub-bacia 3 - 35,23\%; Sub-bacia 4 - 5,52\%, conforme Quadro 2.

Empreendimento turístico e de lazer administrado pelo governo estadual. 
Quadro 2. Unidades cadastradas nas 4 (quatro) sub-bacias

\begin{tabular}{l|r|r|r|r|r}
\hline Tipo da Unidade & $\begin{array}{c}\text { Sub- } \\
\text { bacia 1 }\end{array}$ & $\begin{array}{c}\text { Sub- } \\
\text { bacia 2 }\end{array}$ & $\begin{array}{c}\text { Sub- } \\
\text { bacia 3 }\end{array}$ & $\begin{array}{c}\text { Sub- } \\
\text { bacia 4 }\end{array}$ & TOTAL \\
\hline Unidade Residencial (UR) & 196 & 625 & 554 & 85 & 1460 \\
\hline UR/Unidade Mista (UM) & 51 & 97 & 70 & 20 & 238 \\
\hline Unidade Empresarial (UE)/UM & 58 & 94 & 74 & 23 & 249 \\
\hline UE (Unidade Empresarial) & 33 & 57 & 39 & 29 & 158 \\
\hline U (Unidade sem identificação) & 6 & 22 & 13 & 3 & 24 \\
\hline TOTAL GERAL & 344 & 875 & 760 & 160 & 2.129 \\
\hline
\end{tabular}

Fonte: Prefeitura Municipal de Belém, Secretaria Municipal de Habitação - SEHAB, 2007. In: MALHEIRO, 2009, p. 121.

De acordo com os registros realizados $74,7 \%$ das residências são compostas de até cinco pessoas, enquanto 23,4 \% são formadas por mais de seis e até 20 pessoas; a renda familiar varia de 1 a 2 salários mínimos; 80,5\% dos imóveis são de propriedade particular, 53,39\% correspondem às famílias que residem a mais de dez anos no imóvel; 28,91\% são famílias em que as mulheres assumem a função de chefes de família; as casas, em sua maioria, são de madeira, com dois a cinco cômodos, com padrão construtivo do tipo palafita (construções sobre as águas do Rio Guamá), prevalecendo o uso das águas do rio como local de destino dos dejetos e do lixo (PMB, 2007).

Figuras 4, 5 e 6. Fotos da obras e da Orla de Belem
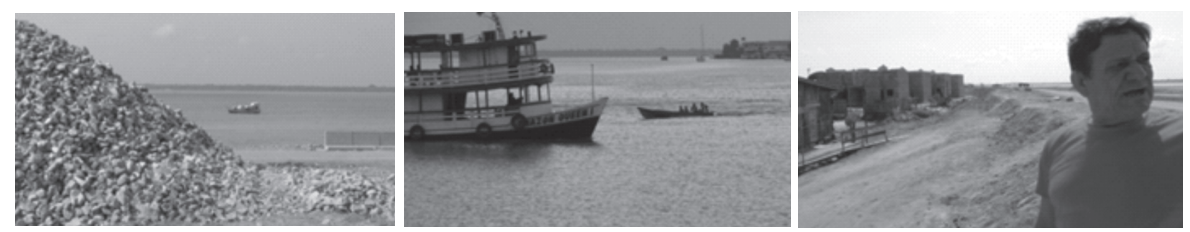

Fotos: Edna Castro

Figuras 7, 8 e 9. Fotos de casas de moradores que resistem à demolição
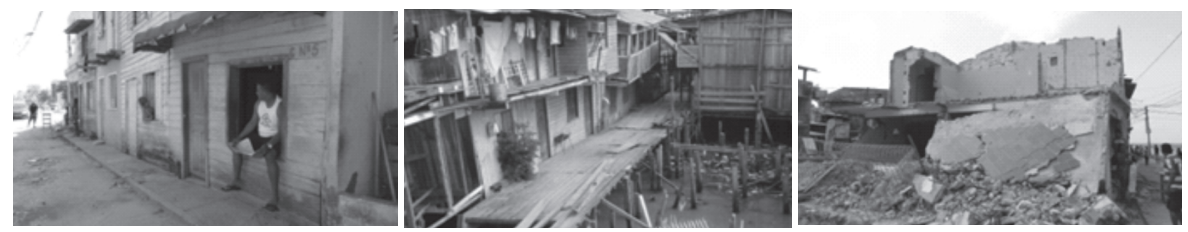

Fotos: Edna Castro 
Figuras 10, 11 e 12. Residencial concluído e em obra, na Orla e Galerias em instalação
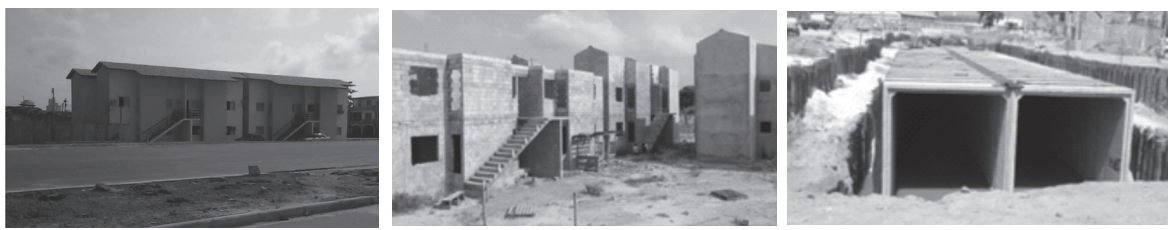

Fotos: Edna Castro e Joaquim Castro

Figura 13. Vista das obras do Portal a partir do Mangal das Garcas

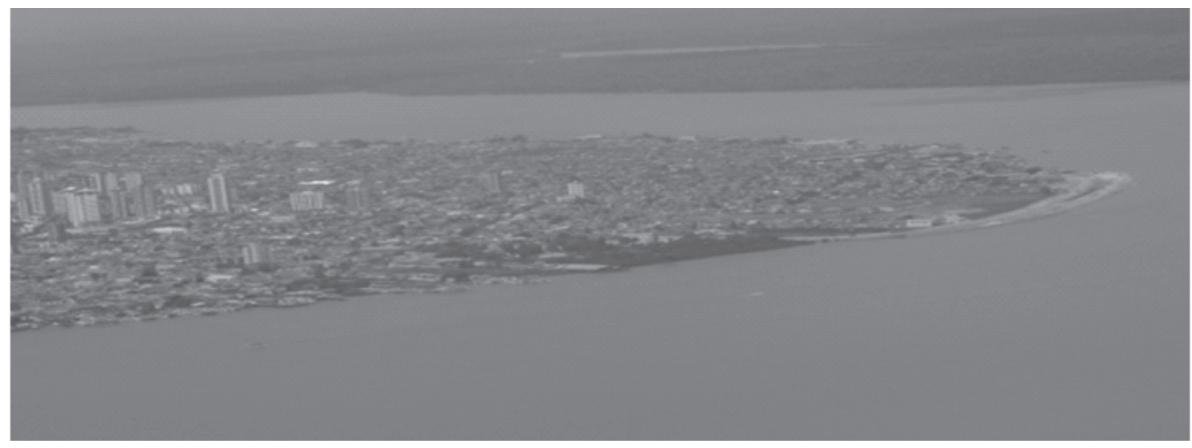

Foto: Edna Castro

Em sua modalidade de macrodrenagem a partir da intervenção urbanística realizada pelo PROMABEN, em sua primeira etapa, o total de imóveis afetados é de 436 unidades. Sendo 272 residenciais, 120 comerciais e 44 mistas, atingindo 355 famílias do trecho Av. Bernardo Sayão, entre a Rua Veiga Cabral e Oswaldo de Caldas Brito. O processo de negociação com as famílias iniciou em junho de 2010 e até o momento não foi finalizado, pois de acordo com os moradores entrevistados, o projeto Portal da Amazônia, embora represente a conquista de um sonho antigo, não deveria ter sido pensado sem a participação da população, que só aconteceu sob a pressão do Ministério Público do Estado que, ao ser acionado pelas dezenas de abaixo-assinados, convocou o poder público para apresentar e esclarecer as ações previstas. Tal processo foi permeado de conflitos, que gerou diversas manifestações públicas, audiências públicas e com o prefeito, no sentido de se incorporar as contribuições dos moradores.

São movimentos de resistência principalmente em relação às soluções de remanejamento, indenização e auxílio-aluguel, uma vez que extrapolava a situação das famílias que se encontravam nas palafitas do rio Guamá, ampliando-se para os domicílios localizados em áreas de terra firme, além das divergências em relação aos 
valores das indenizações que não ultrapassam o valor de $\mathrm{R} \$ 25.000,00$, aprovado no contrato de financiamento com o BID. Foram questões que serviram de elemento mobilizador das comunidades residentes nos quatro bairros pertencentes à Bacia da Estrada Nova. As mobilizações fizeram com que a PMB e as empresas terceirizadas para executar a obra abrissem espaço para incorporar as reivindicações populares, bem como asseguraram espaços de participação nas instâncias do projeto, elegendo representantes para as comissões de fiscalização de obra.

Os processos de mobilização que ocorrem durante todo o percurso do projeto Portal da Amazônia, seja no trecho do projeto Orla, seja no trecho do PROMABEN, coloca em questão o modelo urbanização moderna adotada pelo poder público aliado ao poder das empresas privadas, como é o caso da aliança PMB e BID, que tem na política de saneamento a sua principal estratégia de limpeza da cidade e consequente embelezamento, numa medida em que a cidade se consolida como o lugar da valorização econômica e da mercantilização da terra e da habitação para obtenção de lucros. Nesse sentido, o Direito à Cidade passa ao largo de intervenções desse tipo, com o direito à moradia sendo incorporada apenas como ação focal, destinada aos que sairão de suas casas para outras áreas de assentamento humano. Aos que ficarão terão, além do saneamento, apenas a sorte de conseguirem permanecer em suas residências, mesmo que sem nenhum apoio de melhoria de habitabilidade, uma vez que essa situação não faz parte do programa, deixando para as famílias encontrarem a solução de forma individualizada, vulnerabilizando as famílias moradoras das áreas de intervenção.

É importante frisar ainda que, ao mesmo tempo em que os moradores das áreas almejam melhoria de habitabilidade, os mesmos têm clareza de que o projeto Portal da Amazônia não foi concebido para eles que residem no lugar por mais de dez, vinte, trinta ou até quarenta anos. No dizer de um dos entrevistados " $a$ Prefeitura planejou tudo direitinho para quando a obra concluir a gente sair daqui. Porque não temos condições de pagar pelo espaço valorizado urbanisticamente”.

Por esse exemplo, é importante refletir acerca de um determinado modus operandi que faz com que o Estado, aliado aos setores da economia capitalista, e da avassaladora corrida imobiliária que tomou de assalto as cidades brasileiras, de continue produzindo cidades para o "estrangeiro", para atrair mais investimentos de grandes negócios, negando as formas estruturantes que também produzem a cidade, como é o caso dos trabalhadores que residem nas áreas circunscritas ao projeto.

Mobilização social e territorial nas áreas de intervenção do projeto Portal da Amazônia: Mobilização dos Moradores da Av. Bernardo Sayão e da Travessa Quintino Bocaiúva (Sub-Bacia 2) e áreas em processo de intervenção urbanística - 2010 
Figuras 14 e 15. Manifestação pública e reunião em áreas atingidas.
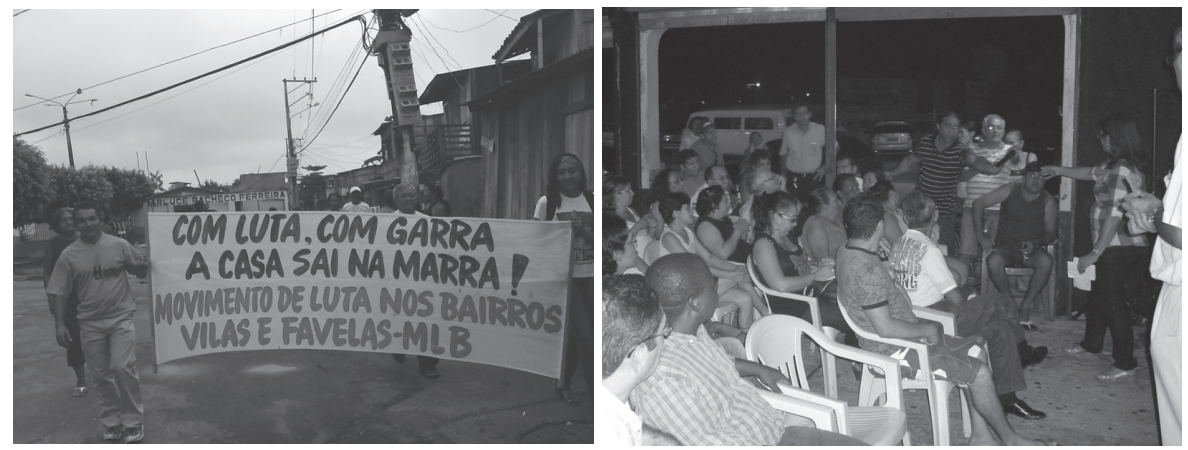

Fonte: PMB, Movimento de Lutas nos Bairros, Vilas e Favelas (MLB) e trabalho de campo, 2011.

\subsection{O Prosamim}

Em Manaus, no ano de 2006, o poder público deu início ao PROSAMIM, constituindo-se em programa de intervenção urbanística, cujo principal objetivo é solucionar o grave problema da falta de saneamento nas áreas sem infraestrutura urbana e que foram ocupadas, em sua maioria, pela população de baixa renda, principalmente a que habita às margens dos igarapés. Pela sua localização, Manaus possui uma rede hidrográfica de grande complexidade, com diversos igarapés que ao longo do tempo foi sendo ocupado e adensado por contingentes populacionais migrantes, sem que houvesse qualquer intervenção pública, no sentido de ordenar, planejar e controlar a situação.

De maneira a reagir e enfrentar a questão, o poder público deu início em 2006 ao Programa Social, Ambiental e Urbanístico (PROSAMIM), que até o ano de 2009 já havia beneficiado, em sua primeira etapa, cerca de 8 mil famílias que moravam à margem ou sobre o leito dos igarapés. Dos onze igarapés que já sofreram intervenção, já foram concluídos os igarapés do Passarinho, dos Franceses, de Manaus, da Cachoeirinha, Bittencourt, do Quarenta e o Mestre Chico, envolvendo aproximadamente 10 mil famílias, com ações diversas, tendo a centralidade em processos de remanejamento-reassentamento. De acordo com a equipe do PROSAMIM, os objetivos principais do programa estão referidos à drenagem dos igarapés, transformando-os em canais, a partir da técnica do aterramento desses cursos d'água e da extinção da ocupação favelizada do seu entorno. A pesquisa desenvolvida concentrou sua observação nas áreas que compõem a Bacia do Educando, em função de que nessa localização o programa encontra-se em fase de finalização da intervenção urbanística. 
Nesse sentido, os primeiros igarapés a sofrerem intervenção do programa estão localizados na Bacia do Educando que abriga cerca de 580 mil habitantes, com uma extensão territorial de $39 \mathrm{~km}^{2}$, envolvendo 33 igarapés, 15 bairros e o Distrito Industrial, banhando toda a área central de Manaus e apresenta uma densidade demográfica de 115hab/ha, conforme pode-se verificar na Figura abaixo.

Nessa área o PROSAMIM buscou resolver o problema da habitação, urbanismo e questões sanitárias. Foram atingidas diretamente com remoção 1.845 famílias e 7.820 pessoas distribuídas do seguinte modo: igarapé de Manaus atingiu 449 famílias de um total de 1.821 pessoas; igarapé do Bittencourt atingiu 329 famílias de um total de 1.431 pessoas; e o igarapé Mestre Chico atingiu 1.067 famílias de um total de 4.568 pessoas.

De acordo coma documentação oficial do programa, nessa Bacia residiam cerca de 21 mil famílias sob risco de desabamento e inundação, dado a falta de saneamento básico, assoreamento, drenagem insuficiente e inundação e em decorrência de tal situação o governo do estado do Amazonas buscou como solução a intervenção urbanística nos igarapés ocupados e em seu entorno, buscando recursos junto ao BID. O contrato firmado com esse Banco ficou na órbita de US\$ 430.000.000,00 e contrapartida na ordem de US\$ 270 milhões, composto em três contratos: O primeiro assinado em 2006 no valor de US\$ 200 milhões; o segundo em 2008 no valor de US\$220 milhões e o terceiro em 2009 no valor de US\$ 110 milhões, de 66 milhões de dólares para a primeira etapa da intervenção, a ser executada até 2013. Até março de 2011 o BID já desembolsou $80,81 \%$ (BID, 2011).

O programa tem como objetivo principal "contribuir para solução dos problemas ambientais, sociais e urbanísticos que afetam a população da cidade de Manaus" e tem como políticas de atuação as seguintes ações: Áreas de intervenção abaixo da cota de 30msnm de inundação do Rio Negro; Atuação nos aspectos sociais, ambientais, urbanísticos, econômicos e institucionais; Consulta pública junto à comunidade envolvida e sociedade civil organizada; Gestão participativa do Programa; Remoção das famílias das áreas de risco; Oferta de moradias dignas nas áreas próximas e em conjuntos habitacionais de outras zonas da cidade; Urbanização do entorno; Recuperação das edificações de interesse histórico. No que tange aos aspectos socioambientais o programa elegeu como linha de atuação as nascentes dos igarapés; qualidade da água dos igarapés; habitação; aspectos urbanísticos; saneamento básico; (drenagem, água, esgoto, lixo); saúde; segurança pública; esporte e lazer; áreas verdes; cultura; organização comunitária (PROSAMIM, 2009).

As soluções definidas no programa para as situações de deslocamento das famílias atingidas pela intervenção são as mesmas definidas pelo Portal da Amazônia em Belém, qual seja: Remanejamento, indenização, auxilio-moradia 
ou indenização assistida e solo criado. Na Bacia dos Educandos o programa já finalizou sua intervenção, estando na fase da pós-ocupação. Tem-se, então, que no ano de 2009, 6.355 famílias $^{7}$ foram remanejadas dos Igarapés Manaus, Bittencourt e Mestre Chico, Quarenta e Cachoeirinha, com as seguintes soluções:

Quadro 3. Famílias Atendidas pelo PROSAMIM no aspecto habitacional

\begin{tabular}{|l|c|}
\hline $\begin{array}{c}\text { Solução encontrada pelo programa para a } \\
\text { questão moradia }\end{array}$ & Número de família atendida \\
\hline Indenizações & 2.289 \\
\hline Bônus Moradia & 1.986 \\
\hline Casas no Conjunto habitacional & 1.111 \\
\hline Unidades habitacionais em Solo Criado & 969 \\
\hline TOTAL & 6.355 \\
\hline
\end{tabular}

Fonte: PROSAMIM, 2009

Essas soluções revelam que o programa, embora se constitua uma referência política tanto para o governo federal brasileiro quanto para o BID, enquanto agente financiador, adotou como principal medida a solução do remanejamento, uma vez que as famílias atingidas num primeiro momento não acreditavam na possibilidade de permanecerem assentados nas áreas de moradia originária, encontraram na solução da indenização e do remanejamento a solução mais imediata para resolver a questão da moradia, uma vez que as famílias remanejadas para os conjuntos habitacionais construídos pela Superitendência de Habitação (SUHAB) para essa finalidade específica encontravam-se na condição de inquilinos ou viviam enconstados em residencias cedidas por parentes, amigos, etc.

Na estrutura de gestão do programa a SUHAB é responsável pelo Plano de Reassentamento das famílias atingidas pelo programa de saneamento e conforme informativo eletrônico, a SUHAB afirma que

"Para inicio e realizações das obras do Prosamim é necessária a retirada dos imóveis na envoltória da obra, para isso os proprietários são indenizados, através de um levantamento sócio econômico realizado pelas assistentes sociais da Suhab/ Prosamim. Os relatórios ainda são encaminhados para avaliação técnica da engenharia do programa, que junto ao proprietário escolhem a forma de indenização, podendo o proprietário escolher pelo pagamento da avaliação do imóvel, realizada por um profissional qualificado ou ainda uma casa em um conjunto do programa habitacional do Estado. Nesses oito anos 10.489 imóveis foram indenizados pelo Programa Suhab/ Prosamim, para isso foram gastos mais de R\$350 milhões". (http://www.suhab.am.gov.br/home/modules.php?name=Con tent\&pa $=$ showpage\&pid $=3$, acessado em 30 de janeiro de 2012). 
No Quadro 4 pode-se verificar as soluções viabilizadas pela SUHAB no período de 2005 a 2006:

Quadro 4. Beneficiários com casas segundo conjuntos, projeto PROSAMIM.

\begin{tabular}{|l|c|c|c|c|c|}
\hline \multicolumn{7}{|c|}{ Beneficiários com casas através do PROSAMIM } \\
\hline \multicolumn{1}{|c|}{ Conjunto } & Localidade & Período & Suhab & Prosamim & Total \\
\hline Indenizações & Manaus & 2005 à 2009 & - & 4.468 & 4.468 \\
\hline Bônus & Manaus & 2005 à 2009 & - & 2.480 & 2.480 \\
\hline Cheque moradia & Manaus & 2005 à 2009 & - & 1.696 & 1.696 \\
\hline $\begin{array}{l}\text { Total de } \\
\text { Beneficiários }\end{array}$ & & & - & 8.644 & 8.644 \\
\hline
\end{tabular}

Fonte: http:/ / www.suhab.am.gov.br/home/modules.php?name=Content\&pa=showpag e\&pid=3, acessado em 30 de janeiro de 2012.

Além dessas soluções viabilizadas pelo PROSAMIM por meio da SUHAB foram construidas ainda 9,5 mil casas populares financiadas ao servidor público e destinadas a permuta com as famílias beneficiadas pelo Prosamim no Conjunto Nova Cidade, cuja entrega foi concluída em 2006 e está localizado na Cidade Nova, Zona Norte de Manaus, considerada área periférica dessa cidade.

a) Conjunto Carlos Braga:

b) Conjunto Nova Cidade.

As unidades habitacionais destinadas às famílias atingidas pelo PROSAMIM são localizadas nos conjuntos habitacionais construídos nas áreas consideradas de expansão urbana e se encontram nos bairros da zona norte da cidade, distante, portanto, dos equipamentos urbanos já consolidados nas áreas centrais, onde as famílias residiam.

É ilustrativo ainda as soluções encontradas para resolver o problema da moradia aliado ao problema ambiental, em Manaus. Nesse sentido, as áreas antes definidas como de assentamentos humanos, agora são espaços do lazer contemplativos, talvez pouco utilizados pelas populações que antes residiam nesses lugares, uma vez que em decorrência das alternativas de remanejamento, muitas famílias foram assentadas em áreas distantes do seu local de origem. É importante salientar que a questão da moradia em Manaus tem sido objeto de intensos conflitos entre população atingida, poder público e movimentos sociais organizados, registrando-se a existência de muitas áreas de assentamentos precários à margem de qualquer planejamento urbano, e que continuam enfrentando problemas estruturais de não acesso à infraestrutura física e social.

Durante o trabalho de campo foi possível identificar que o processo de execução do programa na Bacia do Educando foi permeado por divergências e conflitos, pois à medida que o programa avançava alguns segmentos reagiam em decorrência das soluções apresentadas e em função das áreas que inicialmente não 
haviam sido contempladas. Para a coordenação do movimento de reforma urbana de Manaus, o caso do Igarapé Cachoeirinha, é um exemplo de luta pela permanência na área que sofreu a intervenção urbanística, pois os moradores não queriam ser remanejados e o governo não quiz negociar, "o governo foi tirando de um por um até o movimento não mais resisitir [] se ve ver tá muito bonito, sonhar com aquele serviço ali para depois não usufruir da mesma, não tiveram oportunidade e estão a mais de $20 \mathrm{~km}$ da cidade, na periferia.... as familias do PROS AMIM estão pulverizadas na cidade, estão no Coroado, no Japiim, Alvorada, etc." (Entrevista com liderança do Fórum da Moradia de Manaus, 2011).

Outra situação de conflitou identificada no âmbito do PROSAMIM está relacionada com a intervenção na comunidade São Benedito, conhecida como "Beco dos Pretos", no Morro da Liberdade. Rata-se de uma comunidade de negros, remanescente de quilombo e que foi dispersarda a partir da intervenção urbanística do PROSAMIM. Pois, para atender as famílias do Igarapé do mestre Chico, o programa construiu as unidades habitacionais na modalidade "solo criado", em cima do "Beco", cortando-o ao meio e com isso as famílias tiveram que ser indenizadas. Para a liderança, moradora do "Beco" há mais de 45 anos, significon uma perda e uma agressão ao convívio de décadas de uma comunidade que tradicionalmente realizava suas atividades culturais, como a festa do divino, a festa de São Benedito e outras (Entrevista com liderança do Beco dos Pretos, 2009).

Em Manaus a intervenção urbanística realizada pelo PROSAMIM reconfigurou a fisionomia da cidade que antes convivia com a realidade dos assentamentos precários sobre os igarapés existentes na cidade. A cidade ficou mais bonita e aparentemente mais organizada. Contudo, é perceptível também que a moradia ainda se evidencia como uma questão para o poder público e para sociedade, haja vista que a transformação feita pelo programa tornou as áreas centrais mais valorizadas e, portanto, potencialmente cobiçada pela ação do mercado. Seja o mercado imobiliário, turístico, indústrial, educacional e outros. À medida que o programa avança a cidade vai obtendo maior consolidação em sua infraestrutura urbana, dinâmica fundamental para a acumulação capitalista.

\section{CONSIDERAÇÕES FINAIS}

O referencial teórico-metodológico adotado possibilitou a análise das intervenções urbanísticas em metrópoles amazônicas a partir de duas cidades que se mostram como de grande relevância para dinâmica regional e nacional, no que tange aos aspectos econômicos, sociais, culturais e ambientais e que se encontram nos dias atuais buscando formas de despontar num cenário mundializado, em que a dimensão territorial emerge como lugar de concorrência financeira. E nesse sentido, as cidades são vistas como o lugar de mercantilização das relações sociais.

No caso da Amazônia, as cidades despontam como potencialidade para a dinâmica capitalista, sobretudo as suas metrópoles, haja vista a sua diversidade 
cultural e a relação que as mesmas estabelecem com a natureza, diferenciando-se das demais cidades capitalistas em nível mundial e, assim, tornando-se elemento de atração para os órgãos de fianciamento internacional, cujo compromisso maior é com os representantes do grande capital, fazendo com que suas ações nos países em desenvolvimento contribuam para o circuito internacional da economia e, portanto, para as “condições gerais da produção". É necessário, então, retomar a perspectiva teórica que aponta a cidade e sua urbanização como fenômeno próprio das sociedades capitalistas,tal como nos afirma Jean Lojkine (1981). Ou seja, para esse autor, [...] a aglomeração da população, dos instrumentos de produção, do capital, dos prazeres e das necessidades - em outras palavras a cidade - não é de modo algum um fenômeno autônomo sujeito a leis de desenvolvimento totalmente distintas das leis de acumulação capitalista, onde a esfera da produção, a da troca e a do consumo estão em constante interação (LOJKINE, 1981; p. 139, grifo do autor).

Por essa perspectiva podemos vislumbrar que a expectativa do Direito à Cidade e o Direito à Moradia Digna vão sendo distanciados cada vez mais, ou quem sabe vaõ se reduzindo às práticas urbanísticas que têm na "renovação-deportação" a sua principal ação. Desse modo, como tornar as metrópoles amazônicas mais acessíveis? Mais democráticas? De modo que os diferentes segmentos possam usufruir do produto e do resultado das intevenções de grandes projetos urbanos?

Em Belém, a transformação das áreas sem infraestrutura urbana em áreas urbanizadas podem ser compreendidas como esse lugar de valorização econômica e "aglomeração urbana", que desorganiza a vida social e cultural das famílias que fazem uso dos espaços circunscritos ao projeto Portal da Amazônia. A melhoria habitacional enquanto objetivo do projeto não aponta ações que possam de forma efetiva reverter o quadro de precarização de grande parte da população atingida. São trabalhadores ribeirinhos que terão suas vidas afetadas, moradores que passarão a ocupar lugares mais distantes; as áreas incluem ainda os portos e trapiches públicos, de uso popular, ameaçados de extinção, pois são serviços e circuitos que não fazem parte de modo explícito da intervenção urbanística que ora acontece na Bacia da Estrada Nova.

Enquanto que em Manaus, o PROSAMIM, ao modificar as áreas centrais da cidade, embelezando-as, busca aliar ações de realocação humana com ações de sustentabilidade urbana. Ao retirar a população das áreas afetadas pelo programa, o poder público, por meio da política habitacional reproduz um novo processo de periferização nessa cidade, deslocando as famílias para conjuntos habitacionais distantes dos locais de origem e construídos com a finalidade de reassentá-las. Aquelas que optam por permanecer nas unidades habitacionais construídas em bairros centrais, devem passar por capacitação específica no sentido de que se adaptem à nova moradia, na modalidade apartamentos. Contudo, tanto em Belém como em Manaus a metodologia adotada pelos programas provocou um processo que levará à desorganização das relações sociais, econômicas, políticas e culturais 
das populações atingidas e, quiçá, não conseguirão atender à demanda de moradia, saneamento e infraestrutura urbana dos segmentos historicamente excluídos.

Finalmente o referencial teórico-metodológico possibilitou que se constatasse que nas duas cidades, as intervenções urbanísticas, potencialmente, reproduzirão a perspectiva política que tem a cidade como mercadoria, tornando-a campo de competividade, e, assim, propagando uma das idéias-força do planejamento estratégico que é a competitividade urbana, segundo a qual as cidades devem competir pelos investimentos de capital, tecnologia e competência gerencial e atrair novas indústrias, negócios e força de trabalho qualificada. Nessa perspectiva, a cidade é, em si mesma, mercadoria vendida em um mercado bastante competitivo e complexo, para o qual as dimensões simbólicas inscritas em sua história, sua cultura e identidades são apropriadas pelo circuito mercantil.

\section{REFERÊNCIAS}

APPADURAI, Arjun - Dimensões culturais da globalização. Lisboa: Teorema, 2004.

BICALHO, Reestruturação rural e participação política no entorno de Manaus. In: ARAÚJO, Roberto e LÉNA, Philippe. (Orgs.). Desenvolvimento Sustentável e Sociedades na Amazônia. Belém: MPEG, 2011. p. 409-443.

CASTRO, Edna. Fronteira e Territorialidades: Atores locais e conexões transnacionais. In: FELDMAN, Sarah; FERNANDES, Ana. O Urbano e o Regional no Brasil Contemporâneo. Mutações, tensões, desafios. Salvador, EDUFBA/UNESP/ANPUR, 2007.

CASTRO, Edna. Urbanização, pluralidade e singularidades das cidades amazônicas. In: CASTRO, Edna (org.). Cidades na Floresta. São Paulo: Annablume, 2008.

CASTRO, Edna. O urbano plural e multietnico: trabalho, forma de sociabilidade e diferença em espaços de fronteira na Pan-Amazônia. Caxambu, $35^{\circ}$ Encontro Anual da ANPOCS, outubro de 2011 (Anais do Encontro).

DEAN, Warren. A Industrialização durante a República Velha. In: FAUSTO, Boris. (org.). História Geral da Civilização Brasileira.Tomo III. O Brasil Republicano, v. 1, Estrutura do Poder e Economia (1889-1930). São Paulo: DIFEL, 1977.

DIEGUES, A. C. O mito do paraíso desabitado nas florestas tropicais brasileiras. In: CASTRO, Edna e PINTON, Florence. Faces do Trópico Úmido Conceitos e Questões sobre desenvolvimento e meio ambiente. Belém: CEJUP, 1997.

GEERTZ, Clifford. Savoir local, savoir global. Paris: PUF, 1986.

GODELIER, Maurice. A racionalidade dos sistemas econômicos. In: Carvalho, Edgard de (Org.) Godelier - Antropologia. Coleção Grandes Cientistas Sociais. São Paulo: Ática, 1981.

HATOUM, Milton. AMAZONAS CAPITAL MANAUS. In: NUNES, Benedito e HATOUM, Milton. CRÔNICA DE DUAS CIDADES - BELÉM e MANAUS. Belém: SECULT/PA, 2005. 
Instituto Brasileiro de Geografia e Estatística. Censo Demográfico, 2000.

Instituto Brasileiro de Geografia e Estatística, 2009.

Instituto Brasileiro de Geografia e Estatística. Censo Demográfico, 2010.

OLIVEIRA, José Aldemir de; SCHOR, Tatiana. Manaus: transformações e premanências, do forte à metrópole regional. In: CASTRO, Edna (org.). Cidades na Floresta. São Paulo: Annablume, 2008.

Pesquisa Nacional por Amostragem de Domicílios. IBGE, 2008.

POCHMANN, Marcio. Enfrentar o desafio da desigualdade. Anais do Seminário Internacional sobre o Desenvolvimento. Brasília/DF, março de 2009. Capturado em 20 de janeiro de 2010, em www.unb.br

PREFEITURA DE BELÉM. Estudo de Impacto Ambiental do Programa de Recuperação Urbana e Ambiental da Estrada Nova - PROMABEN. Belém: Engesolo Engenharia Ltda/PMB, 2003.

PREFEITURA MUNICIPAL DE BELÉM. Projeto de Trabalho Técnico Social. Portal da Amazônia, Sub-Bacia I. CONTRATO 222.629-71/2007, Belém, 2007.

Prefeitura debate Portal da Amazônia com sociedade. Belém, 2010a. Disponível em: <http://www.belem.pa.gov.br/>. Acesso em 21 julho 2010a.

Portal da Amazônia muda a cara de Belém. Belém, 2010b. Disponível em: $<$ http://www.belem.pa.gov.br/>

LÉVI-STRAUSS, C. O pensamento selvagem. Campinas: Papirus, 1989.

MALHEIRO, Bruno Cezar Pereira. Portos, Portas e Postais: experiências, discursos e imagens produzindo a orla fluvial de Belém (PA). 2009. Dissertação de Mestrado (Programa de Pós-Graduação em Planejamento do Desenvolvimento - PLADES) - Núcleo de Altos Estudos Amazônicos, Universidade Federal do Pará.

MARTINELLO, Pedro. A Batalha da Borracha durante a Segunda Guerra Mundial. Rio Branco: Cadernos UFAC, série Estudos e Pesquisas 1, 1988.

MARINI, Rosa; CASTRO, Edna. Negros do Trombetas. 2. ed. Belém: CEJUP, 2004.

NUNES, Benedito. PARÁ CAPITAL BELÉM. In: NUNES, Benedito e HATOUM, Milton. CRÔNICA DE DUAS CIDADES - BELÉM e MANAUS. Belém: SECULT/ PA, 2005.

SANTOS, Roberto. História Econômica da Amazônia (1800-1920). São Paulo: T. A. Queiroz, 1980.

SANTOS, Milton. A Urbanização Brasileira. 5. ed., 1. reimpressão. São Paulo: EDUSP, 2008.

SAHLINS, M. P. Idade da pedra, idade da abundância, Lisboa: Teorema, 1972. 